STRUCTURE PROBLEMS OF GENESIS AND PREDICTION OF

\title{
KIMBERLITE PROVINCES
}

\author{
V.A. MILASHEV \\ (Research Institute of the Geology of the Arctic, \\ Leningrad, USSR)
}

1. Kimberlite, picrite rocks and carbonatites were formed by specific processes in the upper mantle of platform areas. Results of study of structure and development regularities of these rocks, physico-chemical conditions of their appearance and production of their melts allow to refine our understanding about main substrate characteristics major tendencies and trend of its evolution.

2. The largest genetically single units of platform ultrabasic volcanic areas are provinces exhibiting in all the case concentriczonal structure. In central parts of provinces as a rule there are oldest kimberlites of diamond subfacies, in mesozone kimberlites of diamond and pyrope subfacies occur together, near the periphery there are youngest kimberlites of "purely" pyrope subfacies and picrites while at margins only rocks of picrite facies, carbonatites and in places complexes of intrusive alkaline and alkaline-ultrabasic rocks. In kimberlite provinces locating on platform margins and near rift areas central zone (diamond subfacies) is absent or poorly developed while peripheral zone usually of large dimensions. Kimberlite provinces of such a type are called semizonal. In number and resources of diamond primary deposits they yield to holozonal provinces.

3. Kimberlite melts were emplaced in mobilized blocks of superheated, low-density matter of the upper mantle embraced by ascending convective currents. In near axial parts of currents where mobilized substrate had highest temperatures melts were generated (produced) at maximum depths while in peripheral zones of currents melting occurred at higher horizons. Radial movement of magma chambers and differentiation of melts followed the mechanism of partial melting.

4. Evolution of kimberlite melts of diamond subfacies occurred at much higher parameters than that of kimberlite melts of pyrope subfacies. During subcrustal period their temperature was on the average 1800 and $1500^{\circ} \mathrm{C}$ while minimum pressure was 45 and $20 \mathrm{~kb}$ respectively. Picrite magmas generated and evoluted at pressure below $20 \mathrm{~kb}$.

5. Main differences of energetic balance, contrast and degree of differentiation of melts producing kimberlites of different subfacies and picrite rocks were established. Minimum values of all these characteristics are typical of kimberlite melts of diamond subfacies while maximum for the group of picrite rocks. 
6. Rocks of differnet facies differ in average contents not only of rock-forming but volatile components as well as autometamorphism regime and so in kimberlite zone of subfacies are found only. serpentine-carbonate metasomatites while around the periphery of provinces fresh monticellite and melilite kimberlites and picrites are common.

7. A model of the upper mantle matter obtained by multidisciplinary study of kimberlites is close to an average composition of nodules of garnet peridotites in kimberlites differing from them in lower $\mathrm{Mg}$ content and higher concentrations of other rockforming elements.

8. The rise to lithosphere base and subsequent tangentianal diffluence of heated matter from the mantle depth were accompanied by the drop of temperature and considerable increase of its viscosity. According to attenuation of "volcanism" rate from central to intermediate and from intermediate to peripheral zones of the Yakut province the value of dynamic viscosity coefficients of mobilized substrate is evaluated as $2.6^{\cdot} 10^{23}$ and $9.8^{\cdot} 10^{23}$ poises on each of these parts respectively.

9. The period of building of each kimberlite province determined by the difference in age of kimberlites in central and peripheral zone is about $250 \mathrm{~m} \cdot \mathrm{y}$. Evolution of kimberlite volcanism with time and space was not limited to period of formation and area of separate diamond provinces. There is a certain cyclicity of kimberlite volcanism on the territory of separate regions that is a subsequent formation of adjacent with space kimberlite provinces of different age with the interval of about 1 billion years. Volcanism of each of these cycles is characterized by a number of peculiar features.

10. Along with concentrical - zonal distribution of rocks of different facies within each kimberlite provinces (macrozonality) there is megazonal structure of kimberlite areas reflected in the existence of peculiar features in kimberlite provinces located inside and on the margins of supercontinents of Gondwana and Laurasia.

11. The most favourable for kimberlite formation were large platforms located in the inner parts of supercontinents. Gondwana and Laurasia for mantle processes responsible for platform magmatism were there more intensive. In the middle of Gondwana there was a southern half of Africa while in the middle of Laurasia a territory of the Siberian platform. The both regions are characterized by maximum development of kimberlites as compared to other areas of corresponding continents.

12. On the basis of regularities recognised it seems possible to predict location, age, and type and consequently diamond possibilities of new kimberlite. From 10 predicted and not yet discovered kimberlite provinces four are within Africa, three in Siberia and one on the Russian platform, one in South America and one in Australia. 